International Review of Research in Open and Distributed Learning Volume 20, Number 3

July - 2019

\title{
Examining Online Health Sciences Graduate Programs in Canada
}

Paige Colley, Karen Schouten, Nicole Chabot, Matthew Downs, Lauren Anstey, Marc S. Moulin, and Ruth E. Martin Western University

\begin{abstract}
Approximately one in 10 employed Canadians worked in health care and social services in 2016. Health professionals perceive life-long learning as an important element of professional life and value flexibility in their continuing education activities. Online learning is ideally suited to meet this need for flexible health sciences continuing education. The present study sought to identify and characterize online graduate programs in health sciences offered by Canadian universities. All Canadian (non-technical) university websites were hand searched for online graduate programs in health and related fields. Each identified program was characterized by 10 features: province, university, flexibility (i.e., fully online or blended), subject area, curriculum (e.g., coursework, thesis or project, practicum), duration and timing options (i.e., full-time, part-time), admission requirements, class size and acceptance rates, and employment outcomes. The search identified 171 Canadian university online graduate programs in health and related fields. Across Canada, the greatest numbers of programs are offered in Ontario and British Columbia. Most programs are master's and graduate certificate programs, with graduate diploma and $\mathrm{PhD}$ programs being less common. While the majority of programs require an undergraduate degree for admission, some programs base entry requirements on previous work experience. Most programs offer a blended learning experience, with fewer being fully online. The most common content areas include nursing, public health, occupational health, and occupational therapy. These findings highlight opportunities to advance fully online, health continuing education in novel subject areas.
\end{abstract}

Keywords: online, health professional, post-secondary education, continuing education, e-learning, Canada 


\section{Introduction}

E-learning, as defined by the Canadian Council on Learning, involves the development of knowledge and skills through the use of technology (Canadian Council on Learning [CCL], 2009). Technology can support engagement with content through online learning activities and tools, and promote interaction among individuals in distance education (Abrami et al., 2006). Many higher education institutions are adopting elearning as a means of providing accessible and flexible educational opportunities to meet the learning needs of students in the 21st century. Indeed, e-learning has become a critical cornerstone in higher education advancement. The number of Canadian adults between the ages of 25 to 64 holding university degrees continues to rise (Statistics Canada, 2013) and post-secondary institutions have reported steady growth in online enrolments since 2015 (Martel, 2015; Bates et al., 2017; Donovan et al., 2018). In 20162017, 17\% of all Canadian post-secondary students were taking at least one online course for credit, and $65 \%$ of those same post-secondary institutions anticipated modest (1-10\%) to fast growth (over 10\%) of their online enrolments over the next year (Donovan et al., 2018). Catering to the growing student demographic of part-time, mature, and working professionals, online education offers convenient, flexible, student-centered educational opportunities (Innes, Mackay, \& McCabe, 2006). For 57\% of Canadian institutions, online learning was rated very important for expanding continuing and professional education programs (Donovan et al., 2018). Moreover, online education allows for universities to increase student access, be more economically competitive by attracting students from outside the traditional service area, improve educational attainment, and provide pedagogical improvements (Abrami et al., 2006; Donovan et al., 2018).

Data from multiple domains provide strong evidence that health education is an area of current and future demand, not only in Canada, but worldwide. As the Canadian population ages, there has been a rise in life expectancy accompanied by chronic conditions such as arthritis, diabetes, and cardiovascular disease (Public Health Agency of Canada, 2016). This demographic change is increasing the demand on healthcare systems, highlighting the need to expand the number of health professionals who possess the competencies and skills required to: 1) adapt to the rapidly evolving health care sectors, and ii) contribute to the complex problem-solving that is required by the health changes of today and tomorrow. E-learning has been found to be an appropriate and effective method for learning health-related content and can be used to meet this growing need for working health professionals (Moore \& Hart, 2004; Shenk, Moore, \& Davis, 2004; Wernet, Olliges, \& Delicath, 2000).

Currently, few studies have investigated onlinelearning opportunities in the health sciences in Canada. This may be attributed to the devolved and distributed structure of the higher education system (Contact North, 2016). Highlighting this gap in the literature presents a time-sensitive and valuable opportunity to further our understanding of online education opportunities in Canada. To our knowledge, no published studies have evaluated the current landscape of online graduate education in the health sciences offered by Canadian universities. Consequently, this research aimed to identify and characterize current online postgraduate programs in health and related fields offered by Canadian universities. The study identified existing program availability and opportunities for further development in novel areas of concentration. 


\section{Methods}

Canadian university websites were manually searched between J anuary 2017 and October 2017 for fully online or blended graduate programs in a health or health-related field. College-level institutions and polytechnic universities were excluded from this study in order to focus on university-based programs. All data were exclusively collected from the university websites; universities were not contacted for further information or clarification about their online programs.

Programs were included in the data analysis if they met the following inclusion criteria: (i) online format, (ii) graduate-level program (e.g., post-baccalaureate certificates, diplomas, master's and PhD), and (iii) in a health or health-related field. To meet the online inclusion criterion, the majority of the program had to be available in an online or blended format. A program was considered graduate-level if a post-secondary degree or equivalent credential was required for admission. A program was defined as a health or healthrelated program if the program's stated intent was to provide education related to health. Health, as defined in the Constitution of the World Health Organization, is a state of complete physical, mental, and social well-being and not merely the absence of disease or infirmity (World Health Organization, 1948).

A list of all Canadian universities was created (see Appendix) and corresponding university websites were searched by three independent researchers, including two bilingual speakers. To identify online health programs that meet set inclusion criterion, a thorough search process was undertaken using the Google search engine, university website search features, and direct access to relevant departmental web pages. This preliminary search yielded 192 programs that were entered into an Excel database. To validate the accuracy of program findings, all university websites were reviewed again by an independent researcher. A cross-comparison of research findings was conducted, along with a consolidated team analysis to review any discrepancies in inclusion. A total of 171 programs met the inclusion criteria following the final phase of data collection.

The data were analyzed iteratively using content analysis. Data were categorized in the database according to: province, university, program name, program type, subject area, learning format, program format, experiential learning, program flexibility, academic admissions, work or volunteer-related admissions criteria, class size, acceptance rates, and job outcomes. Codes were inductively created from recurring patterns in the data, as well as defined and categorized to assist in thematic analysis (Table 1).

Table 1

Codebook Used to Deductively Code Data

\begin{tabular}{|l|l|l|}
\hline Category & Definition & Description of codes \\
\hline Program type & $\begin{array}{l}\text { Coded as certificate, diploma, } \\
\text { master's, doctorate, or other. }\end{array}$ & $\begin{array}{l}\text { Other: if program did not fit into the other four } \\
\text { categories. }\end{array}$ \\
\hline Subject area & $\begin{array}{l}\text { Code based on program title or } \\
\text { program description. }\end{array}$ & Varied \\
\hline Learning format & $\begin{array}{l}\text { Coded as fully online or } \\
\text { blended format. }\end{array}$ & $\begin{array}{l}\text { Fully Online: no requirements to attend campus for } \\
\text { learning, however, an experiential learning }\end{array}$ \\
\hline
\end{tabular}




\begin{tabular}{|c|c|c|}
\hline & & $\begin{array}{l}\text { opportunity such as an internship may be required. } \\
\text { Blended: requires some component of attending } \\
\text { classes, workshops, or retreats on campus. }\end{array}$ \\
\hline Program format & $\begin{array}{l}\text { Coded as thesis, course, } \\
\text { course/ thesis, or } \\
\text { thesis/ project. }\end{array}$ & $\begin{array}{l}\text { Thesis: requires a thesis in addition to required } \\
\text { coursework. } \\
\text { Course: coursework only. } \\
\text { Course/ Thesis: an optional thesis in addition to } \\
\text { required coursework. } \\
\text { Thesis/ Project: optional thesis or project in addition to } \\
\text { coursework. }\end{array}$ \\
\hline $\begin{array}{l}\text { Experiential } \\
\text { learning }\end{array}$ & $\begin{array}{l}\text { Coded as experiential learning } \\
\text { or none. }\end{array}$ & $\begin{array}{l}\text { Experiential Learning: experiential learning } \\
\text { opportunity, either required or optional. Experiential } \\
\text { learning included capstone or culminating project, on- } \\
\text { campus residencies or labs, practicum or internship, } \\
\text { or similar experience. Thesis was not included in } \\
\text { experiential learning. } \\
\text { None: no experiential learning opportunity. }\end{array}$ \\
\hline $\begin{array}{l}\text { Program } \\
\text { flexibility }\end{array}$ & $\begin{array}{l}\text { Coded as flexible or not flexible } \\
\text { based on scheduling options. }\end{array}$ & $\begin{array}{l}\text { Flexible: programs provide options in completion } \\
\text { time, the number of courses students are required to } \\
\text { take concurrently, the range of durations over which } \\
\text { program can be completed, or is offered part-time. } \\
\text { Not Flexible: full-time or a structured format with } \\
\text { specified end date. }\end{array}$ \\
\hline $\begin{array}{l}\text { Academic } \\
\text { admission } \\
\text { requirements }\end{array}$ & $\begin{array}{l}\text { Coded as undergraduate } \\
\text { degree or equivalent, } \\
\text { undergraduate degree plus } \\
\text { additional qualifications or } \\
\text { degrees, academic experience, } \\
\text { or other. }\end{array}$ & $\begin{array}{l}\text { Undergraduate Degree or Equivalent: required an } \\
\text { undergraduate degree, certificate, diploma, or } \\
\text { equivalent credential. } \\
\text { Undergraduate Degree Plus Additional Qualifications, } \\
\text { Degrees, or Academic Experience: previous code } \\
\text { requirements, plus an additional qualification, degree } \\
\text { or academic experience (e.g., registered nurse, or } \\
\text { graduate degree). } \\
\text { Other: required academic admissions other than the } \\
\text { previous two codes. }\end{array}$ \\
\hline $\begin{array}{l}\text { Other admission } \\
\text { requirements }\end{array}$ & $\begin{array}{l}\text { Code based on additional } \\
\text { admission requirements } \\
\text { including work, volunteer } \\
\text { experience, or not a } \\
\text { requirement for admission. }\end{array}$ & $\begin{array}{l}\text { Work Experience: work experience in addition to } \\
\text { academic requirements. } \\
\text { Work or Volunteer Experience: work or volunteer } \\
\text { experience in addition to academic requirements. } \\
\text { Not a Requirement for Admission: did not require } \\
\text { work or volunteer experience. }\end{array}$ \\
\hline Class size & $\begin{array}{l}\text { Code based on availability of } \\
\text { information on class size. }\end{array}$ & $\begin{array}{l}\text { No: information on class size not provided. } \\
\text { Yes: information on class size provided. }\end{array}$ \\
\hline Acceptance rates & $\begin{array}{l}\text { Code based on availability of } \\
\text { information on acceptance } \\
\text { rates. }\end{array}$ & $\begin{array}{l}\text { No: information on acceptance rates not provided. } \\
\text { Yes: information on acceptance rates provided. }\end{array}$ \\
\hline J ob outcomes & $\begin{array}{l}\text { Code based on availability of } \\
\text { information on potential } \\
\text { employment outcomes. }\end{array}$ & $\begin{array}{l}\text { No: potential career outcomes not provided. } \\
\text { Yes: specific career outcomes provided. } \\
\text { Vague: vague or very general careers in health care } \\
\text { noted. }\end{array}$ \\
\hline
\end{tabular}




\section{Results}

The results from the website search identified 171 online graduate programs in a health or health-related field offered across 44 Canadian universities (Table 2). The programs were offered across Canada, in British Columbia ( $n=35)$, Alberta ( $n=26)$, Saskatchewan ( $n=9)$, Manitoba $(n=1)$, Ontario $(n=50)$, Quebec $(n=26)$, New Brunswick $(n=6)$, Nova Scotia $(n=10)$, and Newfoundland $(n=8)$. There were greater numbers of programs available in some provinces, particularly Ontario and British Columbia, likely in accordance to a higher saturation of universities in these provinces. No programs were identified within the Yukon Territory, Northwest Territories, Nunavut, and Prince Edward Island.

Table 2

Summary of Program Findings

\begin{tabular}{|c|c|c|c|c|c|c|}
\hline $\begin{array}{l}\text { Total } \\
\text { programs }\end{array}$ & Program type & $\begin{array}{l}\text { Common } \\
\text { content areas }\end{array}$ & Program delivery & $\begin{array}{l}\text { Program } \\
\text { structure }\end{array}$ & $\begin{array}{l}\text { Experiential } \\
\text { learning }\end{array}$ & $\begin{array}{l}\text { Admission } \\
\text { requirements }\end{array}$ \\
\hline $\begin{array}{l}171 \\
\text { programs }\end{array}$ & $\begin{array}{l}47 \text { certificate } \\
21 \text { diploma } \\
76 \text { master's } \\
4 \text { doctoral } \\
3 \text { combined } \\
20 \text { other }\end{array}$ & $\begin{array}{l}\text { Nursing } \\
\text { Public health } \\
\text { Occupational } \\
\text { health or } \\
\text { physical therapy }\end{array}$ & $\begin{array}{l}76 \text { fully online } \\
92 \text { blended } \\
3 \text { blended or } \\
\text { online }\end{array}$ & $\begin{array}{l}132 \\
\text { flexible, } \\
\text { part-time }\end{array}$ & $\begin{array}{l}111 \text { experiential } \\
\text { education (i.e., } \\
\text { internships, } \\
\text { practicums, } \\
\text { residencies) }\end{array}$ & $\begin{array}{l}89 \text { undergraduate or } \\
\text { equivalent } \\
70 \text { undergraduate } \\
\text { plus additional } \\
\text { qualifications } \\
70 \text { required } \\
\text { work/volunteer } \\
\text { experience }\end{array}$ \\
\hline
\end{tabular}

Of the 171 programs identified, there was a variety of graduate-level credentials, certifications, and degree opportunities in the health field. The results identified 47 certificate, 21 diploma, 76 master's, and four doctoral online health programs. Three combined degree programs, including a graduate diploma and master's degree, and dual-master's degrees, were also identified. Some programs $(n=20)$ did not report the type of graduate credential, or did not classify the program as a certificate, diploma, master's, or doctoral degree (i.e., microprogram).

The most common content areas offered by the online programs included: nursing, public health, and occupational health or physical therapy. This finding was consistent across the certificate, diploma, master's, and doctoral program types, with some variance in subject area frequency and availability. Of the certificate programs, there was a higher prevalence of nursing $(n=13)$, occupational health and safety $(n=5)$, public health $(n=4)$, and mental health $(n=4)$ programs. The diploma programs included varied subject areas, with a higher proportion of nursing $(n=4)$ and health information $(n=3)$ program availability. Of the four $\mathrm{PhD}$ programs identified, three programs specialized in nursing. Finally, there was a higher frequency of nursing $(n=21)$, public health $(n=9)$, social work $(n=7)$, counselling $(n=5)$, occupational therapy $(n=4)$, and clinical science $(\mathrm{n}=4)$ master's programs. Less common were programs in the following subject areas: addiction, anesthesia, clinical epidemiology, food science/ safety, oncology, palliative care, nutrition, health 
and social services, rehabilitation science, dementia, polysomnography, health leadership/management, health education, pediatric psychosocial care, gerontology, child psychology, eHealth, and medical radiation.

The programs identified were delivered fully online, or in a combination of distance and on-campus faceto-face learning experiences, which were referred to as blended. A total of 76 programs were fully online, with a higher proportion of certificate $(n=37)$ and diploma $(n=10)$ programs, compared to master's $(n=14)$ and doctoral $(\mathrm{n}=0)$ degrees. The majority of programs included a blended learning format $(\mathrm{n}=92)$, with mandatory on-campus institutes, courses, residencies, workshops, practicums, and other in-class delivery methods. Three programs offered both blended and fully online learning opportunities, dependent on student preference. Many of the programs ( $\mathrm{n}=132)$ included flexible program structures, with part-timeand self-selected paces. According to program type, many of the certificate $(n=37)$, diploma $(n=17)$, master's $(\mathrm{n}=57)$, and doctoral $(\mathrm{n}=2)$ programs included flexible formats and duration.

In congruence with flexible format structure, a significant portion of the programs offered experiential learning opportunities ( $\mathrm{n}=111)$. These included internships, practicums, residencies, clinical practice, research projects, placements, workshops, labs, and fieldwork. Most of the master's $(n=67)$ and doctoral $(n=4)$ programs offered an experiential education component; whereas, certificate $(n=19)$ and diploma $(n=10)$ programs were less likely to offer hands-on learning experiences. Some of the master's $(n=28)$ and all of the doctoral $(n=4)$ programs offered a thesis or dissertation option.

Most of the programs $(n=89)$ required an undergraduate degree or equivalent for admission into the program. Equivalent qualifications included a college degree, undergraduate-level courses, certificate, or diploma. Some programs $(\mathrm{n}=70$ ) required an undergraduate degree plus additional qualifications, degrees,

or academic experience. For example, a post-secondary education degree or diploma, in addition to registration by an accredited government body (i.e., a Registered Nurse in Canada) or a graduate-level degree were required for admission. Many of the program admission requirements $(n=70)$ included previous work or volunteer experience, which ranged in duration and relevance to the program-area. Finally, few program websites $(\mathrm{n}=14)$ offered information about acceptance rates and class sizes.

While some program websites provided information about employment opportunities and career outcomes, including a list of specific career options or opportunities for advancement in their field, this content tended to be ambiguous or largely undefined for the majority of programs. For example, one Master of Public Health webpage described career opportunities with the following statement: "Career in public health practice."

\section{Discussion}

The present study identified 171 online programs in health or a health-related field offered by Canadian universities. Certificate and master's programs are the most prevalent online health credentials, with fewer online educational opportunities at the diploma or doctoral level. The majority of programs focus on specific disciplines or professions including nursing, public health, and occupational health or therapy; fewer online 
programs take an interprofessional perspective. Many programs offer an experiential learning component, particularly those at the master's and doctoral levels. Less than half of the programs identified were offered fully online, with the remaining programs requiring students to participate in a mandatory on-campus component, which was clearly indicated on the program websites. Thus, there appears to be an opportunity to develop additional, fully online graduate programs in health sciences, particularly at the master's and doctoral level, incorporating interprofessional learning and practice within the program pedagogy.

\section{Limitations}

While procedures were put in place to improve the overall quality of the collected data, there are some limitations to this study. The search strategy used to collect data could have missed programs at universities as the websites of non-health departments, such as education and psychology, were not searched. Some websites were difficult to navigate and information was often not optimally presented, or information was implied rather than explicitly stated. Lastly, since these data reflect only information available to the researchers within the 10-month period of time over which they were collected, and due to the evolving nature of online and program information, the present findings could quickly become outdated. Despite these limitations, the present findings contribute to our understanding of the current state of e-learning across Canadian universities in the field of health.

While most university websites provided program overviews, admission requirements, application process and deadlines, and course information, many program website layouts were difficult to navigate and some information was unable to be retrieved. A limited number of websites provided statistical information regarding acceptance rates and class sizes for prospective students. Highlighting such pertinent information with greater transparency is one avenue for change. In addition, employment opportunities associated with the program were often ambiguous and largely undefined. Program websites should be designed in a comprehensive, accessible manner to attract and inform prospective students. Along with standard program information, websites should offer data and supporting information pertaining to program admissions and employment after graduation.

\section{Future Program Development and Research}

As indicated by the number of applications Canadian universities receive for their graduate program(s) in the health sciences field, there is no shortage of student interest in pursuing a health-related career as indicated. This study suggests that online academic programs are readily available to a vast population of students. As this educational format continues to gain popularity, institutional websites must continue updating their websites to foster the needs of the student population. This includes providing relevant, upto-date information that is presented to interested students in a logical, user-friendly format, allowing for efficient navigation. Today, university students and employed professionals alike, place a high value on flexibility of time and place in their continued educational endeavors. Therefore, the need to provide additional fully online programs that contain experiential learning opportunities is of great importance and 
deserves an in-depth investigation of how this structure of learning can be further integrated into additional university programs throughout Canada.

Future work in this area may deepen our understanding of elearning in Canada by extending the search beyond universities to include colleges and polytechnic universities, and extending the search beyond health science to better understand the availability of e-learning generally. Search strategies could be improved by surveying universities about the number of programs that offer e-learning. Comparing this search to similar searches in other countries with online health science programs would develop our understanding of how Canada fits into the global context of e-learning.

\section{Conclusions}

This research aimed to identify current online graduate programs in the health sciences offered by Canadian universities. As this research suggests, there is a critical and continual need for online graduate programs to be structured in a format that allows for an optimal level of accessibility and flexibility for the student population. While this type of education is increasing among Canadian institutions, findings suggest that this program configuration is particularly lacking at the master's and doctoral level. Additional fully online post graduate programs that align with personal demands of potential students such as ongoing work and family commitments are needed. 


\section{References}

Abrami, P.C., Bernard, R. M., Wade, A., Schmid, R. F., Borokhovski, E., Tamin, R. ...Peretiatkowicz, A. (2006). A review of elearning in Canada: A rough sketch of the evidence, gaps and promising directions. Canadian J ournal of Learning \& Technology, 32(3), 2-35. DOI: 10.21432/T2QS3K

Bates, T., Desbeins, B., Donovan, T., Martel, E., Mayer, D., Paul, R., ... Seaman, J . (2017). Tracking online and distance education in Canadian universities and colleges: 2017. Vancouver, BC: The National Survey of Online and Distance Education in Canadian Post-Secondary Education. Retrieved from the Canadian Digital Learning Research Association website: https:// onlinelearningsurveycanada.ca/ publications/

Canadian Council on Learning. (2009). State of e-learning in Canada. Retrieved from http:// en.copian.ca/ library/ research/ ccl/ elearning/ elearning.pdf.

Contact North. (2016). Canada a leader in online, open, and flexible learning. Retrieved from https:// contactnorth.ca/ sites/ default/ files/ pdf/ externalpresentations/canada_a leader_in online learning.pdf

Donovan, T., Bates, T., Seaman, J., Mayer, D., Martel, E., Paul, R., ...Poulin, R. (2018). Tracking online and distance education in Canadian universities and colleges: 2018. Vancouver, BC: Canadian Digital Learning Research Association. Retrieved from the Canadian Digital Learning Research Association website: https:// onlinelearningsurveycanada.ca/ publications/

Innes, A., Mackay, K., \& McCabe, L. (2006). Dementia studies online: Reflections on the opportunities and drawbacks of elearning. J ournal of Vocational Education and Training, 58(3), 303-317. DOI: $10.1080 / 13636820600955567$

Martel, C. (2015). Online and distance education capacity of Canadian universities. Retrieved from https:// www.tonybates.ca/ wp-content/ uploads/ANALYSIS-AND-REVIEW-of-Canada-DistanceEducation-2015-EN-final-1-1.pdf

Moore, P., \& Hart, L. (2004). Strategies for teaching nursing research online. International Nursing Review, 51(2), 123-128. DOI: 10.1111/j.1466-2435.2004.00231.x

Public Health Agency of Canada. (2016). How healthy are Canadians? A trend analysis of the health of Canadians from a healthy living and chronic disease perspective. Retrieved from https:// www.canada.ca/ content/ dam/phac-aspc/documents/ services/publications/ healthyliving/how-healthy-canadians/pub1-eng.pdf

Shenk, D., Moore, L., \& Davis, B. (2004). Teaching an interdisciplinary distance education gerontology course: Benefits of diversity. Educational Gerontology, 30(3), 219-235. DOI:

$10.1080 / 03601270490273141$ 
Statistics Canada. (2013). Education in Canada: Attainment, field of study and location of study. DOI: 99012-X2011001

Wernet, S. P., Olliges, R. H., \&Delicath, T. A. (2000). Postcourse evaluations of WebCT (Web Course Tools) classes by social work students. Research on Social Work Practice,10(4), 487-504. DOI: $10.1177 / 104973150001000408$

World Health Organization. (1948). Summary report on proceedings minutes and final acts of the international health conference. Retrieved from http://apps.who.int/iris/ bitstream/10665/85573/1/Official_record2 eng.pdf 


\section{Appendix}

\section{List of University Websites Searched}

\begin{tabular}{|c|c|c|c|}
\hline Province & University & Website link & Reasons for inclusion/ exclusion \\
\hline Alberta & Ambrose University & https://ambrose.edu/ & No graduate health courses \\
\hline Alberta & Athabasca University & http:// fhd.athabascau.ca/ & Yes \\
\hline Alberta & Burman University & https:// www.burmanu.ca/ & No graduate health courses \\
\hline Alberta & $\begin{array}{l}\text { Concordia University of } \\
\text { Edmonton }\end{array}$ & https:// concordia.ab.ca/ & Yes \\
\hline Alberta & King's University & https:// www.kingsu.ca & No graduate health courses \\
\hline Alberta & $\begin{array}{l}\text { Grant MacEwan } \\
\text { University }\end{array}$ & https:// www.macewan.ca/ & Yes \\
\hline Alberta & Mount Royal University & http:// www.mtroyal.ca/ & Yes \\
\hline Alberta & St Mary's University & https:// www.stmu.ca/ & No graduate health courses \\
\hline Alberta & University of Alberta & https:// www.ualberta.ca/ & Yes \\
\hline Alberta & University of Calgary & http:// werklund.ucalgary & Yes \\
\hline Alberta & University of Lethbridge & https:// www.uleth.ca/ & Yes \\
\hline British Columbia & Capilano University & https:// www.capilanou.ca/ & No graduate health courses \\
\hline British Columbia & $\begin{array}{l}\text { Emily Carr University of } \\
\text { Art and Design }\end{array}$ & http:// www.ecuad.ca/ & No graduate health courses \\
\hline British Columbia & Simon Fraser University & https:// www.sfu.ca/ & Yes \\
\hline British Columbia & $\begin{array}{l}\text { Thompson Rivers } \\
\text { University }\end{array}$ & https:// www.tru.ca/ & Yes \\
\hline British Columbia & $\begin{array}{l}\text { Trinity Western } \\
\text { University }\end{array}$ & https:// www.twu.ca/ & Yes \\
\hline British Columbia & $\begin{array}{l}\text { University of the Fraser } \\
\text { Valley }\end{array}$ & https:// www.ufv.ca/ & Yes \\
\hline British Columbia & $\begin{array}{l}\text { University of British } \\
\text { Columbia }\end{array}$ & http:// www.mrsc.ubc.ca/ & Yes \\
\hline British Columbia & $\begin{array}{l}\text { University of Northern } \\
\text { British Columbia }\end{array}$ & https:// www.unbc.ca/ & No \\
\hline British Columbia & Royal Roads University & http:// www.royalroads.ca/ & No graduate health programs \\
\hline British Columbia & University of Victoria & https:// www.uvic.ca/ & Yes \\
\hline British Columbia & $\begin{array}{l}\text { Vancouver Island } \\
\text { University }\end{array}$ & https:// programs.viu.ca/ & Yes \\
\hline British Columbia & University Canada West & https:// ucanwest.ca/ & No graduate health programs \\
\hline British Columbia & $\begin{array}{l}\text { University of British } \\
\text { Columbia Okanagan }\end{array}$ & $\begin{array}{l}\text { http:// ok.ubc.ca/ welcome.h } \\
\text { tml }\end{array}$ & Yes \\
\hline British Columbia & Quest University & https:// questu.ca/ & No graduate health programs \\
\hline British Columbia & $\begin{array}{l}\text { Fairleigh Dickson } \\
\text { University }\end{array}$ & http:// www.fdu.edu/ & $\begin{array}{l}\text { No online graduate courses offered from } \\
\text { Vancouver campus or online }\end{array}$ \\
\hline Manitoba & Brandon University & https:// www.brandonu.ca/ & Yes \\
\hline Manitoba & University of Manitoba & http:// umanitoba.ca/ & No online graduate health programs \\
\hline Manitoba & University of Winnipeg & https:// www.uwinnipeg.ca/ & No graduate health programs \\
\hline Manitoba & $\begin{array}{l}\text { University College of the } \\
\text { North }\end{array}$ & $\begin{array}{l}\text { https:// www.ucn.ca/ default } \\
\text { ed.aspx }\end{array}$ & No graduate health programs \\
\hline Manitoba & $\begin{array}{l}\text { Canadian Mennonite } \\
\text { University }\end{array}$ & http:// www.cmu.ca/ & No graduate health programs \\
\hline Manitoba & $\begin{array}{l}\text { Providence University } \\
\text { College }\end{array}$ & http:// www.prov.ca/ & No graduate health programs \\
\hline Manitoba & Booth University College & https:// www.boothuc.ca/ & No graduate health programs \\
\hline
\end{tabular}




\begin{tabular}{|c|c|c|c|}
\hline Manitoba & $\begin{array}{l}\text { Université de Saint- } \\
\text { Boniface }\end{array}$ & https:// ustboniface.ca/ & No graduate health programs \\
\hline New Brunswick & Université de Moncton & https:// www.umoncton.ca/ & No online graduate health programs \\
\hline New Brunswick & Mount Allison University & $\begin{array}{l}\text { https:/ / www.mta.ca/ Prospe } \\
\text { ctive/ Default.aspx }\end{array}$ & No graduate health programs \\
\hline New Brunswick & St Thomas University & http:// w3.stu.ca/ stu/ & No graduate health programs \\
\hline New Brunswick & $\begin{array}{l}\text { University of New } \\
\text { Brunswick }\end{array}$ & http:// www.unb.ca/ & Yes \\
\hline New Brunswick & Crandall University & http:// www.crandallu.ca/ & No graduate health programs \\
\hline New Brunswick & St Stephen's University & http://ssu.ca/ & No graduate health programs \\
\hline New Brunswick & University of Fredericton & https:// www.ufred.ca/ & No undergraduate admissions requirements \\
\hline New Brunswick & Kingswood University & $\begin{array}{l}\text { https:// www.kingswood.ed } \\
\text { u/ }\end{array}$ & No graduate health programs \\
\hline New Brunswick & Yorkville University & http:// www.yorkvilleu.ca/ & Yes \\
\hline $\begin{array}{l}\text { Newfoundland \& } \\
\text { Labrador }\end{array}$ & $\begin{array}{l}\text { Memorial University of } \\
\text { Newfoundland }\end{array}$ & https:// www.mun.ca/ & Yes \\
\hline Nova Scotia & Dalhousie University & https:// www.dal.ca/ & Yes \\
\hline Nova Scotia & Saint Mary's University & https:// www.smu.ca/ & Yes \\
\hline Nova Scotia & Acadia University & $\begin{array}{l}\text { https:// www2.acadiau.ca/ in } \\
\text { dex.php }\end{array}$ & No graduate health programs \\
\hline Nova Scotia & $\begin{array}{l}\text { Mount Saint Vincent } \\
\text { University }\end{array}$ & http:// www.msvu.ca/ & Yes \\
\hline Nova Scotia & $\begin{array}{l}\text { University of King's } \\
\text { College }\end{array}$ & https:// ukings.ca/ & No graduate health programs \\
\hline Nova Scotia & $\begin{array}{l}\text { St Francis Xavier } \\
\text { University }\end{array}$ & https://www.stfx.ca/ & Yes \\
\hline Nova Scotia & Cape Breton University & https:// www.cbu.ca/ & No graduate health programs \\
\hline Nova Scotia & Université Sainte-Anne & $\begin{array}{l}\text { https:// www.usainteanne.c } \\
\text { a/ }\end{array}$ & No graduate health programs \\
\hline Ontario & Algoma University & https:// www.algomau.ca/ & No graduate health programs \\
\hline Ontario & Brock University & https:// brocku.ca/ & Yes \\
\hline Ontario & Carleton University & https:// carleton.ca/ & No online graduate health programs \\
\hline Ontario & Lakehead University & https:// www.lakeheadu.ca/ & Yes \\
\hline Ontario & Laurentian University & https:// laurentian.ca/ & Yes \\
\hline Ontario & McMaster University & $\begin{array}{l}\text { https:// www.mcmastercce.c } \\
\text { a }\end{array}$ & Yes \\
\hline Ontario & Nipissing University & http:// www.nipissingu.ca/ & No graduate health programs \\
\hline Ontario & Queen's University & http:// www.queensu.ca/ & Yes \\
\hline Ontario & Saint Paul University & https:// ustpaul.ca/ & No graduate health programs \\
\hline Ontario & $\begin{array}{l}\text { Redeemer University } \\
\text { College }\end{array}$ & https:// www.redeemer.ca/ & No graduate health programs \\
\hline Ontario & University of Sudbury & https:// www.usudbury.ca/ & No graduate health programs \\
\hline Ontario & Ryerson University & http:// www.ryerson.ca/ & Yes \\
\hline Ontario & OCAD University & https:// www.ocadu.ca/ & No online graduate health programs \\
\hline Ontario & University of Guelph & https:// www.uoguelph.ca/ & Yes \\
\hline Ontario & University of Toronto & http:// www.utoronto.ca/ & Yes \\
\hline Ontario & University of Ottawa & https:// www.uottawa.ca/ en & Yes \\
\hline Ontario & University of Waterloo & https:// uwaterloo.ca/ & Yes \\
\hline Ontario & University of Windsor & http:// www.uwindsor.ca & Yes \\
\hline Ontario & Western University & https:// www.uwo.ca & Yes \\
\hline Ontario & Wilfrid Laurier University & https:// www.wlu.ca/ & No online graduate health programs. \\
\hline Ontario & Trent University & https:// www.trentu.ca/ & No online graduate health programs. \\
\hline Ontario & York University & http:// www.yorku.ca/ & Yes \\
\hline $\begin{array}{l}\text { Prince Edward } \\
\text { Island }\end{array}$ & $\begin{array}{l}\text { University of Prince } \\
\text { Edward Island }\end{array}$ & http:// www.upei.ca/ & No online graduate health programs \\
\hline
\end{tabular}




\begin{tabular}{|c|c|c|c|}
\hline Quebec & Laval University & $\begin{array}{l}\text { https:// www.ulaval.ca/ en.h } \\
\text { tml }\end{array}$ & Yes \\
\hline Quebec & $\begin{array}{l}\text { McGill } \\
\text { University }\end{array}$ & https:// www.mcgill.ca & Yes \\
\hline Quebec & Bishop's University & http:// www.ubishops.ca/ & No graduate health program \\
\hline Quebec & TELUQ & https:// www.teluq.ca/ & Yes \\
\hline Quebec & Concordia University & https:// www.concordia.ca/ & No graduate health program \\
\hline Quebec & $\begin{array}{l}\text { Université du Quebec à } \\
\text { Montréal }\end{array}$ & https:// uqam.ca/ & No online graduate health program \\
\hline Quebec & $\begin{array}{l}\text { Université du Quebec à } \\
\text { Chicoutimi }\end{array}$ & http:// www.uqac.ca/ & No graduate health programs \\
\hline Quebec & Université de Montréal & http:// www.umontreal.ca/ & Cannot identify relevant programs \\
\hline Quebec & Université de Sherbrooke & $\begin{array}{l}\text { https:// www.usherbrooke.c } \\
\text { a }\end{array}$ & Yes \\
\hline Quebec & $\begin{array}{l}\text { Université du Québec à } \\
\text { Trois-Riviéres }\end{array}$ & https:// www.uqtr.ca/ & Yes \\
\hline Quebec & $\begin{array}{l}\text { Université du Quebec à } \\
\text { Outaouais }\end{array}$ & https://uqo.ca/ & Cannot identify relevant programs \\
\hline Quebec & $\begin{array}{l}\text { Université du Quebec à } \\
\text { Rimouski }\end{array}$ & https:// www.uqar.ca/ & No online graduate health programs \\
\hline Quebec & $\begin{array}{l}\text { Université du Quebec en } \\
\text { Abitibi- Témiscamingue }\end{array}$ & http:// www.uqat.ca & Yes \\
\hline Saskatchewan & University of Regina & https:// www.uregina.ca & Yes \\
\hline Saskatchewan & $\begin{array}{l}\text { University of } \\
\text { Saskatchewan }\end{array}$ & https:// nursing.usask.ca & Yes \\
\hline Saskatchewan & $\begin{array}{l}\text { First Nations University } \\
\text { of Canada }\end{array}$ & http:// fnuniv.ca/ & No graduate health programs \\
\hline
\end{tabular}

\section{Athabasca} University 